substance and range of these essays, which are stimulating and highly readable, both for specialists and general readers. One may, of course, take issue with particular points: does abortion really constitute a right to avoid duties? Does it matter if men and women have different moral and legal rights in relation to abortion? Is the denial of the father's right to prevent an abortion not due to this being a "positive" right (requiring action by another person) rather than a "negative" or civil right (of the type discussed in Weber's essay)? If Tay Sachs disease means that "the child's basic interests are all thwarted" (page 127) (and that is perhaps debatable), that may justify an abortion but can one take the further step of imposing a duty on the mother to abort? However, the intellectual response provoked by the essays is part of the enjoyment of reading them!

LOANE SKENE Associate Professor and Director of Studies, Health and Medical Law, Law School,

The University of Melbourne, Australia

\section{Changing Conceptions of Motherhood}

Edited by Derek Morgan, London, British Medical Association, 1996, 74 pages, $£ 6.95$.

\section{Considering Surrogacy}

London, British Medical Association and Human Fertilisation and Embryology Authority, 1996, 11 pages, $£ 5.20$.

"Six weeks after his birth, George and Dianne knew that little Jack would soon be theirs legally. They were all grateful for the helpful advice and direction that their general practitioner had given them and for showing Tracy (the partial surrogate) how to do the artificial insemination herself. Dianne hoped desperately that Tracy (who of course was the legal mother until the parental order could be obtained), would not change her mind and decide to keep Jack as she knew she was entitled to do under the terms of the Human Fertilisation and Embryology Act (1990), by which instrument no surrogacy arrangement was enforceable. George and Dianne had been surprised, that, despite having lived together for the best part of ten years, they were advised to become married well before the birth otherwise they would not be able to request the parental order making him their son legally. It also seemed bizarre to Dianne that despite Tracy's estranged husband really having nothing much to do with the whole affair, he was still Jack's legal father until the parental order was obtained - at least he didn't object, which really would have made things diffcult! At night she often wondered how Jack would feel at the age of 18 when, even if she and George decided to hide the terms of his birth, he could seek out the registrar of births and obtain his birth certificate on which was written the name of his birth mother. Would he still regard Tracy as his real mother, or would the fact that she, Dianne, had brought him up as his social and legal mother really count? They were still undecided what to do. Perhaps she'd discuss it again with the counsellor whom her GP had arranged for her.

"How mean it was that according to the Surrogacy Arrangements Act (1985), she couldn't pay Kim and the other members of the Womb with a View Club as she knew that would have been illegal. Nevertheless she felt a great debt to them for arranging for her to meet Tracy and for her to be the surrogate, especially since she knew that she could not have advertised for her in the newspaper - no editor would have touched it with a barge pole as that too would have been illegal under the Act. She hoped that the $£ 10,000$ that she gave Tracy would compensate her adequately for her having to give up her job, and for all the travelling to and fro for antenatal care. Strange how some people thought that no money could change hands in a surrogacy arrangement but then she wasn't being paid, it was just 'reasonable expenses'."

How well informed George and Dianne were - thanks to the help of their knowledgeable general practitioner, who clearly had read Changing Conceptions of Motherhood - the Practice of Surrogacy in Britain. This is not a rip-roaring read, nor a taxing ethical discussion about surrogacy, nor is it meant to be. It is a considered and factual account of the practice of

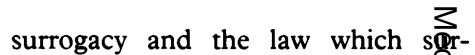
rounds it, and of its medical aspects, plus a useful discussion of the psyclogical aspects of surrogacy and need and place of counselling.

There is a real need for this li $\overrightarrow{\overline{\text { gglle }}}$ book, as may be seen from the preceding scenario. Many practition ess, whether general or specialist, find 鹿e whole area confusing, and to many so fraught with legal traps as to makeit a method of treatment well worth steying clear of. This too is the complaint of many women, who, as a last resørt, would like at least to discuss the posgibility but have no idea where to tuw, as their own health professionals क्ञ⿰冫欠 scared and ill-informed. The bợk clarifies terminology such as parfial and full surrogacy; who is the father; parental orders and adoption; bigh registration, and the terms of the Afts relevant to the practice of surrogaey. The amended Surrogacy Arrangements Act (1985) is included for god measure. Despite at times being a $\Phi_{i t}$ legally turgid, it should be mandat $\bar{x} y$ reading for all involved with the dekivery of assisted conception and shoytd be available in libraries for those wis ing to clarify the issues.

Help is at hand for the consuner too. The BMA/HFEA have pubsd jointly an informative 11-page bøolfest which is derived from the above bogk, but has been simplified in a questiognand-answer style to make it useful-to women considering surrogacy. As with the book, it deals with the legal position, the status of the child, parental orders and criteria for becoming a surrogate mother. Questions to do th the involvement of medical professionals, the benefits of counselling and the health risks are all raised qudd answered, as is the implication for gie child and others. Although the läguage has been highly simplified I believe it will still be too difficult for many who are in greatest nefd. Nevertheless its general usefulns cannot be doubted. It will be of betzfit not only to those considering surrogacy, but to anyone simply interested in what surrogacy is about and whrtit entails. It will also be useful to sogre who are more peripherally involyed health care professionals, and inde्ed to students who wish to have a quamek preview of the issues in order to decide if more in-depth reading is requirgd.

PETER R BRAUBE

Professor of Obstetrics and Gynaecolgy

United Medical and Dental Schoolsof Guy's and St Thomas's Hospitals,

London 